\title{
MANAGING RELIGIOUS AND ETHNIC DIVERSITY FOR PEACE AND HARMONY: ISLAM AND BUDDHISM IN THE MALAY WORLD OF SOUTH EAST ASIA
}

\author{
Imtiyaz Yusuf \\ Mahidol University, Thailand \\ Email: imtiyazy@gmail.com
}

\begin{abstract}
This article discusses the phenomenon of the relationship between Islam and Buddhism in the Malay World of Southeast Asia. The ultimate goal is to uncover social facts about the relationship between adherents of the two largest religions in Southeast Asia: Islam (42\%) and Buddhism $(40 \%)$. This research shows that the relations between Islamic and Buddhist communities in various Southeast Asian Countries are full of dynamics. The dynamics can take the form of peaceful relations or vice versa: conflicts with various levels of escalation. Among the reasons that also triggered the emergence of conflict is the problem of political, economic, socio-cultural, and religious disparities. The solution to this problem can be done with a historical approach, an intra and interfaith dialogue approach in order to foster mutual understanding between adherents of both religions, a political policy approach in the form of granting basic rights to followers of a minority religion, and an academic approach through the study of religions in various universities in Thailand, Malaysia, Singapore, Indonesia and various other countries in the Southeast Asian region. Meanwhile, Islamic studies in various Islamic universities need to be done with an interdisciplinary approach and understanding of languages and cultures that exist in Asian countries.
\end{abstract}

Keywords: Ethnic and Religious Diversity, Harmony and Peace, Islam, Buddhism

\section{Introduction}

The Southeast Asian Region is one of the regions in Asia that is very diverse in various aspects: religion, ethnicity, race, and culture. From the aspect of religion there are two religions with the most followers in this region, namely adherents of Islam and Buddhism with respectively reaching $42 \%$ and $40 \%$. In addition to Islam and Buddhism, people in this region are adherents of Christianity, Catholicism, Hinduism, Confucianism, and local religions. With the diversity of this Southeast Asian region, the potential for violent conflict in the name of various interests, including religion, is certainly quite large.

This article tries to raise the phenomenon and reality of diversity in the Southeast Asian region from religious aspects, namely the facts about the relationship between Islam and Buddhism in the Malay World of Southeast Asia. Southeast Asia is the only part of the Muslim world that has a direct relationship with Buddhism. The harmonious relations of adherents of the two main religions in this region have long been established. However, lately this good relationship began to be disrupted by the emergence of conflicts between Buddhists and Muslims in some regions and then spread to other regions, such as Sri Lanka, Myanmar, and Thailand. 
When the Southeast Asian region began to feel the impact of the global era and the rise of Asia (China and India), the various dimensions of Islam and the lives of Muslims also felt its influence. Among the effects of globalization on Islam in this region is the emergence of the phenomenon of negative imaging of Islam and Muslims in various regions of Southeast Asia. Islam is perceived as a religion of violence and terrorism that threatens peace in the region. This has more or less elicited Islamophobic attitudes among non-Muslims in this region. The true face of Islam as a peaceful and tolerant religion is hidden because of this negative image. Islamic dialogue and relations with non-Islamic religions are not well developed.

Maybe in addition to religious, social, cultural factors, there are economic and political factors that cause Islam in Southeast Asia to stigmatize. However, apart from the various root problems, efforts to build dialogue and harmonious relations between religions and adherents of religions in this region need to be done. Muslim academics and researchers must take an important part in building this dialogue and relations.

This study aims to describe the reality of the relationship between adherents of Islam and Buddhism in various regions in Southeast Asia, the roots of the conflict, and alternative solutions to overcome them academically, sociologically, culturally, economically, and politically. This research is analytic descriptive. Descriptions are made to explain the reality of the relationship between Islam and Buddhism in Southeast Asia based on observations and data from various written sources such as mass media, books, scientific journals and relevant documents. The analysis is carried out by linking the facts with religious, social, cultural, economic and political aspects, both theoretically and empirically.

\section{Muslim-Buddhist Ethno Conflict in Southeast Asia}

In this section we will describe the reality of the conflict between adherents of Islam and Buddhism in several Southeast Asian regions. This section will also explain the causes of the conflict both historically and sociologically, politically, and culturally.

\section{Ethno-Religious Conflict in Southern Thailand}

The conflict between Muslims and Buddhists in Southern Thailand is actually more ethnic than religious. The conflict in this region was started by a rebellion of Muslim nationalists who wanted to have their own sovereignty over the area where they lived. So this conflict is more political with ethnic and religious dimensions. Actually this conflict is not directly related to the international Jihadist movement. This conflict had arisen long before the trans-national Islamic movement (Jihadi). Conflict resurfaced in 2004 after brief breaks in the 1980s and 90s. So far the conflict has resulted in 7,000 deaths.

Historically the conflict began in 1906 when Siam annexed the Muslim kingdom of Patani in South Malaysia. This annexation was strengthened by the Anglo-Siam agreement in 1909 in which the British recognized the Siamese sovereignty over Pattani. In return, Siam recognized British control of the Malay states of Kelantan, Kedah, Perak and Perlis. Since 1909, Siam began a policy of assimilation and centralization, namely enforcing the language, culture and administrative system of Thailand in three provinces of Southern Malaysia. 
Most state officials appointed in the South are Buddhists, who are unfamiliar with the local Malay language, culture and religion. This often causes social conflict and political resistance of Malay Muslims towards all things considered as arrogance and domination of Thai culture.

The Siamese government gave religious freedom to Malays, namely freedom to practice Islam as a religion and for family law namely religious autonomy, but at the same time Siamese also tried to replace local Malay languages and dialects with Thai language and also replace Malay culture with Thai culture. With this kind of policy, Malay Muslims in Southern Thailand, who have their own culture, language and religion that are different from Thai Buddhists, feel that the Thais have usurped their freedom and even colonized Malay lands. In other words, the conflict in Southern Thailand has its roots in the neglect of local culture, language, religion and social practices of the Malay Muslim population. In other words, we can conclude that the issue of religion is not the only cause of conflict in Southern Thailand. The real root of the problem for decades is economic neglect, lack of employment opportunities for the local Muslims in both public and private sectors, cultural insensitivity of the bureaucracy and the non-recognition of the religion, linguistic and cultural diversity within Thai polity (Yusuf 2007).

So what actually happened was a rebellion that was local and cultural in nature, and had no relevance to the local or trans-national jihadist Islamic movements (Report 2005).

Ethno-religious conflict in Southern Thailand between Muslims and Buddhist rulers resulted in the destruction of social relations between Malay Muslims and Thai Buddhists, who are currently at the lowest level with distrust and alienation on both sides. Many Buddhists migrated from the three Southern provinces. The Thai state used excessive force in handling conflicts, for example the mosque incident on April 28, 2004, and the Takbai incident on October 25, 2004 which occurred during the Thaksin regime and resulted in many deaths. A Muslim online media based in Canada responded to the Takbai incident by saying that Thaksin was the "Butcher of Bangkok" who avoided use of democratic means to resolve the conflict (www.muslimedia.com 2004). Malay nationalists in the separatist movement are trying to break off the South far from that part of the country. While the majority see autonomy as an acceptable option.

Over the past 50 years, many political groups and movements have been formed to support Pattani's political goals. The current uprising is largely faceless. The guerrillas have now mingled with the local population and are planning to come to the surface after getting enough support in the field from the local Malay community. The Barisan Revolusi Nasional - Coordinate (BRN-C) is considered the main rebel group at present. He rose again in 1990 and recruited a new and younger generation of traditional rebels.

\section{Rohingya Tragedy in Burma}

Myanmar, formerly known as Burma, is a country with a plural population both in ethnic and religious terms. The population until July 2012 amounted to 54,584,650. In terms of ethnicity, the majority of Myanmar's population consists of Burmans (68\%). The rest are other ethnic groups, namely Shan (9\%), Karen (7\%), Rakhine (4\%), Chinese (3\%), Indians $(2 \%)$, Mon $(2 \%)$. All of these ethnic groups are recognized as citizens. There is one other ethnic group, Rohingnya (5\%), but this ethnic group is not recognized as a citizen. 
MANAGING RELIGIOUS AND ETHNIC DIVERSITY FOR PEACE AND HARMONY: ISLAM AND BUDDHISM IN THE MALAY WORLD OF SOUTH EAST ASIA

Imtiyaz Yusuf

From the aspect of religion, the biggest adherents of the religion are Buddhists (89\%). Other religions embraced by the population of Myanmar are minorities, namely: Christians 4\% (Baptists 3\%, Roman Catholics 1\%), Muslims 4\%, animists 1\%, others 2\%.

Myanmar's Muslim population consists of: 1) Burmese Muslim groups; 2) Indian Muslims from Bangladesh, India, Pakistan; 3) Rohingya Muslims are from Bengali; 4) Panthay Muslims, namely Chinese Muslims from Yunnan; and 5) Zerbadi Muslims, the community of descendants of marriages between Muslim foreign men (South Asian and Middle Eastern) and Burmese women. In Myanmar there are 3,000 Sunni mosques and 9 Shia mosques.

Rohingyas are a minority tribe in West Burma. In 2012 there were estimated to be around 800,000 Rohing tribes. As a result of conflict and persecution, many Rohingnya people have left Burma. The UN describes them as one of the most persecuted minorities in the world. The Burmese military sees its Rohingans as refugees from neighboring Bangladesh and should not be recognized as Burmese citizens. Some historians argue that the Rohingya were formerly survivors of a merchant ship from Saudi Arabia who sank in the sea around Myanmar.

In the document "The1875 Census Report of British Burma (p.30)" it says: "There is one more race that has taken so long in this country to be called indigenous and that is the Arkat Muskatman. This race is descended from voluntary immigrants from the neighboring province of Chittagong, and part of the prisoners brought in the war between Burma and their neighbors ..."

The term Arakan refers to the coastal region between Chittagong and Sandoway and the Rakan kingdom (1430-1638) ruled by Muslim kings. In that region there is peaceful co-existence between Muslims and Buddhists. This area was annexed by the Burmese king Badowpaya in 1785. Subsequently became part of British Burma and now Burma (Yegar 2002).

The population of the Arakan state consists of Rakhine Muslims and Rohingya Muslims. The total population is 5 million people, including 1 million Rohingya populations. Many Rohingnya live in exile. Buddhists Burman and Rakhine refer to the Rohingya as "Kala" which means "skinned skin". This title is a form of racial slur. They are sometimes called "Bengali" people, a derogatory term, different from the "just and gentle" Burman.

It was mentioned in history that General Aung San, the ruler of Burma, promised Ali Jinnah, the founder of Pakistan, to protect and provide security for his Rohing Muslims. Burma became independent under U Nu, Burma's first Prime Minister. U Nu established Buddhism as the state religion of Burma. This policy is against the wishes of ethnic minorities and various religious organizations including Burmese Muslims. When General Ne Wincame came to power in 1962-1988, the status of Muslims changed. One of them, for example, Muslims were expelled from the army corps.

Under the Burmese Independence Act of 1947, Arakanese are declared to have permanent housing in the Burmese Union. In the 1948 the Union Citizenship Act stated, "anyone who is of ancestral origin, who for two generations has made territories included in the Union ... will be considered union citizens." Furthermore, in the 1982 Burmese Citizenship Act Chapter II says: "Citizenship citizens such as Kachin, Kayah, Karen, Chin, Burman, Mon, Rakhine or Shan and ethnic groups who have settled in one of the State's territories as their permanent home from the anterior period until $1823 \mathrm{AD}$ 
was a legitimate Burmese citizen. The State Council can decide who belongs to the national ethnic group and who is not. The name Arakan (Rohingya) is not included in the list of 135 national races recognized by the State.

In 1982 a rule emerged that Rohingya could become citizens if they had an ancestor who had lived in Myanmar since 1823. In 1994, the government of General Than Shew no longer issued birth certificates for Rohingya children. Following pressure from Buddhist groups, the Myanmar government did not give a white card to 400,000 Rohingyas so they could not vote in the 2008 constitutional referendum and national elections in 2010. Rohingyas never finally gained citizenship.

In the face of Burmese oppression several Rohingya resistance movements emerged such as:

1. Mujahid Party - 1947 tried to join Arakan with East Pakistan.

2. North Arakan Muslim League -1948

3. Arakan Liberation Organization (1956-1962) connected with Islamic groups in Pakistan

4. Rohingya Independent Force -1963 also known as the Rohingya Patriotic Front (1974)

5. 1982 Rohingya Solidarity Organization

6. Islamic Front Arakan Rohingya -1987

7. National Arakan Rohingya Organization - 1998

8. Safety of the Rohingya Arakan (ARSA) also known as Harakah al-Yaqin (Movement of Faith). This is a Rohingya rebel group in northern Rakhine State, Myanmar, which emerged in 2015.

After winning the 2015 Myanmar elections by a majority vote, the State Council and Foreign Minister Aung San Suu Kyi, showed his role as a figure behind Burma's current political scenario. He stated that from now on the Rohingya would be referred to as a "Muslim in Rakhine" country which had a majority Buddhist Rakhine population. He also denied that there was a cleansing of the Rohingya ethnic group and suggested the new US ambassador to Myanmar stop using the term "Rohingya". He also had refused a visa for the UN investigation commission to visit Myanmar on the grounds that it would hamper the efforts of the Myanmar government to resolve the issue holistically.

\section{Conflict in Sri Lanka}

Conflicts between Muslims and Buddhists in Sri Lanka cannot be separated from the supremacy of the majority Buddhist group politically. In a conference held by a Buddhist organization called Bodu Bala Sena (BBS), the chairman of BBS, Dilanthe Withanage said that the BBS was trying to protect and revive Sinhalese Buddhism as a political and social force in Sri Lanka after years of erosion under colonial rule and Christian missionary.

Sinhala Buddhist MPs no longer need to fight for the religious and ethnic rights of the majority Buddhists, while lawmakers representing minority religious communities struggle to protect their rights. Thus democracy does not need to work for the majority of Sinhala Buddhists.

The emergence of the Tamil movement was a reason to get rid of Islam in Sri Lanka. BBS as the spearhead of the Buddhist nationalism movement in Sri Lanka is leading the way in campaigning for this. The ongoing conflict and religious disharmony 
MANAGING RELIGIOUS AND ETHNIC DIVERSITY FOR PEACE AND HARMONY: ISLAM AND BUDDHISM IN THE MALAY WORLD OF SOUTH EAST ASIA

Imtiyaz Yusuf

in Buddhist communities in Sri Lanka were highlighted in a conference entitled "Twenty-Five Years of Retrospect: Buddhism, Ethnic Conflicts and Religious Harmony in South and Southeast Asia". The conference was organized by the International Center for Ethnic Studies in June 2014 in Kandy, Sri Lanka.

The escalation of the conflict in Sri Lanka has increased recently after clashes between the majority Sinhalese Buddhists and the Muslim minority in the center of the Kandy district. Sri Lankan government spokesman, Dayasiri Jayasekara, said the emergency status was set for 10 days to control the situation and communal violence that began to spread to other regions. Communal clashes broke out after a group of Buddhists reportedly set fire to a grocery shop owned by a Muslim in the area.

\section{Efforts to Resolve Conflict: A Multidimensional Approach}

A good relationship between followers of Islam and Buddhism in Southeast Asia is not only important for the people of both parties, but also in order to maintain stability, security and peace in the region. Peaceful relations between the two adherents of religion are important pillars in efforts to build a positive future in the Southeast Asian region, especially under the ASEAN organization. Why is it important? Because both religions are the religions with the largest number of adherents in ASEAN. By building good relations, we can help overcome interreligious tensions such as those currently occurring in Myanmar with the Rohingya, in Sri Lanka, Thailand, or elsewhere in the region.

Interfaith Dialogue

Liberal theologian Hans Kung once said that peace between nations would not be possible without interfaith peace. Peace will be realized and the restoration of relations between parties to the conflict can occur, if the community can be awakened, supported by political will and determination to end the conflict. Among the ways and efforts that can be made to bring about peace and overcome religious conflicts in the Southeast Asian region, especially the conflict between Islam and Buddhism is through interfaith dialogue. Interfaith and interreligious dialogue can help resolve interreligious misunderstandings that lead to conflict, to war.

Interfaith and interreligious dialogue are important tools for building interfaith understanding. This religious dialogue must become a permanent activity so that conflict can be quelled before violence occurs. Dialogue is also able to rebuild unity, reconciliation, and create peace. Building dialogue needs to be harmonized with human rights and democracy as a bridge.

Interfaith dialogue needs to be done to foster mutual understanding among fellow believers. However, it is important to remember that religious dialogue must not damage the faith or religious traditions of one or both of the parties to the dialogue.

If it is actually observed between Islam and Buddhism there are points of similarity in several aspects of religious teachings. There is an affinity in theological and ethical messages between the Prophet Muhammad and the Buddha Gautama. Islamic and Buddhist dialogue can begin with the following religious themes:

First, Muslim views about Buddhism. Early Muslims looked at Buddhists as ahl al-Kitab - people in the Book who were similar to the Sabians mentioned in the Qur'an. Professor Muhammad Hamidullah (d. 2002) put forward the view that Buddha is a Prophet (Muhammad Hamidullah 1974) (Scott 1995). Specifically he refers to the mention of the fig tree (ficus religiosa) in the Surah of the Qur'an (Q.S. 95: 1): 
For the sake of figs and olives. For the sake of Mount Tursina. For the sake of a safe country.

Prof. Hamidullah believes that the Buddha sincerely attained Nirvana under the wild fig tree (Ficus religiosa). Because this tree is not included in the lives of the prophets according to the Qur'an, the mention of fig in the Qur'an is a symbolic reference to the Buddha (Hamidullah 1974).

Some interpreters of the Qur'an also believe that the mention of Dhu'l-Kifl might refer to the Buddha's abode, Kapilavastu. (Hamidullah 1974: 54):

And (mention) Ismail, and Idris, and Dhul Kifl. Everything stoic. (Quran 21:85)

And mention Ismael and Elisa and Dhul Kifl. All of the chosen. (Qur'an 38:48)

Such a view is indeed unacceptable to most Buddhists and is seen as an effort to have a Buddha. I only report that such a view exists among Muslims. In contrast to this is the view of many other Muslims who believe that Buddhism is a false religion like any other religion outside of Islam.

An interesting view of the existence of Buddhism comes from the classical Muslim scholar of comparative religion, Muhammad b. 'Abd al-Karim al-Shahrastani (479-548 / 1086-1153). In his book titled Kitab al-Milal wa'l-Nihal (Book of Religious and Philosophical Sects) in the section on Ara 'al-Hind (The Views of the Indians) he said that Buddhism is rich in spirituality. Even according to him the Buddha might be the Prophet Kheer who in the Qur'an is referred to as a seeker of enlightenment (Al-Shahrastani 1910) (Lawrence 1976).

Second, Buddha and Muhammad as seekers of meaning in life. Buddhism and Islam believe that humanity is involved in the search for meaning in life. In the history of religions there were many Buddhas and prophets before the appearance of Gautama Buddha and Muhammad SAW. The Quran for example mentions 25 prophets and messengers including the prophet Muhammad SAW himself. In the Koran 40 verses 78; 4 verse 164, Allah says:

We truly destroyed the apostles before you, some of them. We tell you, and some of them we haven't told you ...

Third, the concept of Minutes. The 14th verse of the Qur'an in verse 4 says: "We have not sent these apostles except verbally the people to explain to you". The Qur'anic concept of treatise or prophecy has similarities or analogous to the concept of Buddhism according to followers of Buddhism in certain matters. Buddha appeared in different epics to teach humans the way to Nirvana or heaven.

Fourth, misery and happiness. Both Prophet Muhammad and Buddha both sought to find answers to ancient questions about human difficulties: what does it mean to be human? Why is there misery and suffering? The Buddha called this phenomenon the term dukkha (suffering). Meanwhile the Qur'an refers to man as a creature created in a state of kabad, which is always in struggle and hard work or suffering (Qur'an 90: 4). Man is free from misery and suffering if he will enter His heaven. Whereas Buddha has the concept of Nirvana. Through nirvana, the Buddha is freed from the shackles of suffering (Dukkha) and enters a state of happiness, relief, peace, calm, free from confusion, turmoil, sadness and distress.

Fifth, the concept of liberation. The messages of the Buddha and Muhammad (PBUH) are messages of liberation through various approaches to truth. In Islam human liberation is carried out through: the doctrine of monotheism which asserts that humans must be free from servitude to false gods and affirm the attachment to God as God 
Almighty. This is what is called theology and morality of Tawheed. Meanwhile the process of human liberation in Buddhism is represented by the concept of Sunyata, emptiness and silence, which is a way to end human exploitation by humans which causes injustice, inequality, and suffering. Sunyata is the Ultimate Reality in Buddhism (Glasenapp 1970).

Sixth, the concepts of moderation and affection. If there is a suggestion in Islam for the ummah to be Ummatan Wasathan, middle people, not extremists, then in Buddhism there is a Majjhima-Patipada teaching, which means "middle ground". The concept of Majjhima-Patipada (Middle Street) in Buddhism and the concept of Ummatan Wasathan (Middle Nation) in Islam have similarities. Both emphasize moderation and offer possibilities for cooperation among diverse religious communities. This is an important concept that must be understood by each adherent of both religions because it can foster mutual understanding and peaceful relations between the two. Moderate attitude is important because so far conflicts often occur because the attitudes of adherents of religion are not moderate and even tend to be extreme (Yusuf 2009).

In Islam and Buddhism there are also teachings about compassion. If in Islam there is a teaching about mercy (compassion), then in Buddhism there is a teaching of karuna which means compassion.

Seventh, the position of the Prophet and Apostle. In Islam, the position of the Prophet is very high, namely as a Prophet and Apostle, Allah's messenger to humans who carry the mission of goodness and truth. The Prophet is an al-Insan al-Kamil. As for Buddhism, a Gautama Buddha is an Enlightened One, a Bodhisattva.

In the future, the concept of human ethics and morality. From the aspects of morality and ethics both Islam and Buddhism teach about the importance of equality, justice, freedom, brotherhood, and liberation from oppression and exploitation.

\section{Fulfillment of Basic Rights without Discrimination}

Conflict between Islam and Buddhism can also be caused by discrimination and non-fulfillment of human rights or basic rights of an individual or community. This treatment is usually experienced by followers of minority religions in the midst of members of a majority religion or a ruler who adheres to a religion different from the religion of its citizens. Therefore the best solution to overcome this problem is to provide equal rights for every citizen and ethnicity in religion. The granting of equality must be constitutionally institutionalized. In some countries, the constitutional guarantee of freedom of religion is widely opposed by some of its citizens. As happened in Myanmar and Sri Lanka, the opposition came from an overwhelming majority of Buddhists to their citizens.

The initial effort to overcome this problem is through a historical approach. This can begin with a study of history. In the past with the existing religious level at that time the Islamic and Buddhist communities were able to live side by side. To restore harmony to the past in the present era requires strong political will on both sides. Unfortunately today religion is more widely used by politicians as a tool to achieve political goals.

\section{Academic Approach to the Study of Religions}

The study of the relationship of religions in the Southeast Asian region that is academic in recent times is rarely conducted. Moreover, studies that are able to bridge 
the attitude of mutual understanding and tolerance among adherents of different religions in the region.

The study of religions that have already taken place should not be carried out with a conventional, apologetic, confrontational and exclusive approach or a reductive social functionalist approach. Studies of Islamic relations with other religions with this kind of approach tend to be normative, by creating religious categories such as faithinfidels or monotheism, and so on. Such a bipolar approach is unable to offer a plausible perspective when speaking of causes of interfaith misunderstanding as causes of conflict and violence in various ASEAN countries.

Academic study certainly requires a different approach, in order to understand the problem comprehensively and objectively. There must be, for example, researchers and academics who master Asian, Sanskrit, Pali, Thai and Japanese languages. This is important so that researchers can better understand Asian religions: Buddhism, Hinduism, Confucianism, Taoism and Shintoism, and their relationship with Islam. Unfortunately, only a handful of Muslim academics in Southeast Asia are trained in modern academic studies on religion and are involved in studies, research and dialogue with Asian religions such as Buddhism, Confucianism, Taoism and Hinduism.

Islamic studies based universities must be more open by including the study of other religions, especially Asian religions, especially for postgraduate students. This is needed in order to increase the understanding of Islamic scholars, researchers and educators about the language, culture and religions of the world and Asia that are needed in building relationships between dialogical religious communities.

With the inclusion of academic studies on Asian religions in Islamic studies, it is hoped that Islamic scholars, researchers and instructors will be born who are sufficiently understanding the diversity of languages, cultures and religions of Asian people themselves. Their understanding is needed for the establishment of dialogue and interfaith relations with other Asian religions. Southeast Asia as part of Asia is a complex geo-cultural region with a diversity of multicultural, multi-ethnic and multi-religious societies.

If researchers and academics understand the diversity of cultures, languages and religions in the Southeast Asian region, the study approach and relations of religions will be balanced and foster mutual understanding among adherents of religions. Since there are only a few Southeast Asian Muslim academics who can be relied on in academic studies, research, and dialogue with other Southeast Asian religions, serious efforts are needed to improve it. Islamic tertiary institutions in Indonesia have good enough capital to implement Islamic studies by expanding the discussion on non-Islamic religions. Indonesia with the Pancasila ideology and long historical experience regarding multireligious and cultural co-existence can be a pioneer in this effort (Yusuf 2017).

Southeast Asian Islamic Studies today has several important tasks. First, it dynamically and critically integrates the study of religion, sasana and social science. This is done by studying and researching Islam and Asian religions as religio-cultural practices based on the idea of social harmony. This is an effort to build Muslim-Buddhist beliefs through education.

Second, Islamic studies in Southeast Asia need to revisit the period (historical perspective) to produce an understanding of Southeast Asian Muslims about citizenship in relation to Muslim minorities in Buddhist countries and Buddhist minorities in Muslim countries. In this context Ismail al-Faruqi in his article (Journal 1979) 
commenting that Islam is not a universalist or ethnic religion, but Islam is a din alfithrah, a natural religion based on the principle of universal humanism. With this principle, according to Faruqi, Islam offers non-Muslims who live in the midst of Islamic society: 1) freedom to believe and not believe; 2) the right to not believe (the case of Christians in Najran); 3) freedom to be different; 4) the right to preserve themselves; 5) the right to work; and 6) the right to rejoice and enjoy beauty - to enjoy their own aesthetics.

Third, Islamic studies in Southeast Asia also need to conduct a balanced study. For the record, Southeast Asian Muslim countries with a Buddhist minority are also not very encouraging in the matter of Islam-Buddhist relations. Policies in countries such as Bangladesh, Malaysia, Indonesia, and Brunei related to Buddhism identified as minority ethnic groups more or less indicate discrimination, although not as excessive as the events that have befallen Rohingnya Muslims, Sri Lanka, and Thailand. However, nonMuslim minorities in the archipelago must be able to enjoy the same freedoms as Muslim minorities elsewhere in Asia and the world. The key to realizing this from the aspect of the study of religions is knowledge. Strong and critical knowledge is an antidote to the emergence of religious conflict and violence. Initiating Muslim-Buddhist understanding of the history of their relationship to establish common ground between them is an academic necessity. Here it should be noted that there are two types of interreligious ignorance. One of them is when followers of one religion don't know another religion. The other is when someone does not want to study other people's religion.

\section{Conclusion}

The relation between followers of the two largest religions in Southeast Asia is a fact and reality that is very dynamic both historically, sociologically, culturally, and politically. A harmonious and peaceful relationship between the two in the past is an important historical record to be a platform for efforts to overcome the phenomenon of conflict in the contemporary era today. In addition to this historical approach, another approach that is also important is religious approach through intra and interfaith dialogue. Dialogue between Islam and Buddhism certainly does not damage the faith, but in order to foster mutual understanding between adherents of both religions. A policy approach in the form of granting basic rights to adherents of minority religions in the countries of the Southeast Asian region also needs to be undertaken by each authority.

From the various approaches offered, the academic approach is also one of the important and strategic efforts. Studies of religions at various universities in Thailand, Malaysia, Singapore, Indonesia and various other countries in the Southeast Asian region have been conducted. In Muslim countries such as Malaysia and Indonesia, Islamic studies must also include themes about the relationship between Islam and other religions in Asia, especially relations with Buddhism which are also widely embraced by Asians. The approach of Islamic studies is not enough with the normative and bipolar or eurosentric approaches, but also the interdisciplinary approach, including an understanding of languages and cultures that exist in Asian countries. The approach of Islamic studies must also be carried out in the form of interfaith dialogue. Only in this way can we hope to grow and develop mutual understanding between various adherents of religions in Southeast Asia, especially Islam and Buddhism. 
Journal of Malay Islamic Studies

Vol. 1 No. 1, June 2017 
MANAGING RELIGIOUS AND ETHNIC DIVERSITY FOR PEACE AND HARMONY: ISLAM AND BUDDHISM IN THE MALAY WORLD OF SOUTH EAST ASIA

Imtiyaz Yusuf

\section{Bibliography}

Al-Shahrastani, Muhammad b. Abd al-Karim. 1910. Kitab Al-Milal Wa 'l-Nihal. Cairo: Ma'ba'at al-Azhar.

Glasenapp, Helmuth Von. 1970. Buddhism: A Non-Theistic Religion. London: George Allen and Unwin.

Journal, Institute of Muslim Minority Affairs. 1979. 'Hak-Hak Non-Muslim Di Bawah Islam: Aspek Sosial Dan Budaya'. 1(1): 90-102.

Lawrence, Bruce B. 1976. Shahrastani on the Indian Religions. Hague: Mouton.

Muhammad Hamidullah, Muhammad Rasullah. 1974. 42 Buddhism and Islam: Past to Present Encounters and Interfaith Lessons. Hyderabad: Habib \& Co.

Report, Asia. 2005. 'International Crisis Group, "Southern Thailand: Insurgency, Not Jihad"'. Report, Asia:37-38.

Scott, David. 1995. 'Buddhism and Islam: Past to Present Encounters and Interfaith Lessons'. 42: 141-55.

www.muslimedia.com. 2004. “"Thailand's Thaksin Unfazed by Condemnations after Latest Massacre of Muslims'.

Yegar, Moshe. 2002. 'Antara Integrasi Dan Pemisahan: Komunitas Muslim Filipina Selatan, Thailand Selatan, Dan Burma Barat/Myanmar'.

Yusuf, Imtiyaz. 2007. 'The Southern Thailand Conflict and the Muslim World'. Journal of Muslim Minority Affairs 27: 334.

- - - 2009. Dialogue Between Islam and Buddhism through the Concepts Ummatan Wasatan (The Middle Nation) and Majjhima-Patipada (The Middle Way)". Islamic Studies.

- - - 2017. 'Asia Tenggara Perlu Perkuat Studi Agama-Agama'. https://www.uinjkt.ac.id. 